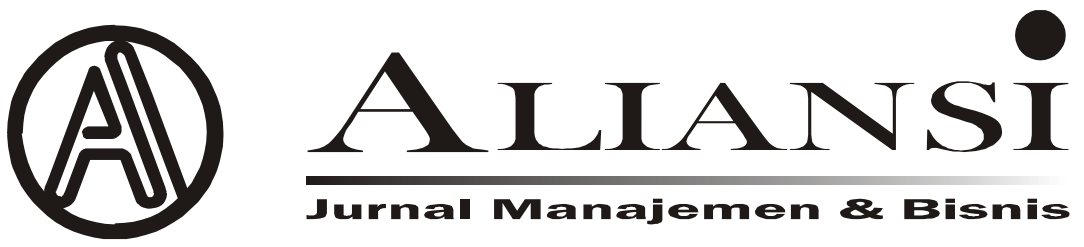

\title{
MANAJEMEN LABA DENGAN INDIKATOR PENYEBABNYA
}

\author{
Oleh : Fitri Purwiyanto, Inung Wijayanti, Stephani Nauli
}

email : inung@perbanas.id

\begin{abstract}
The objectives of this study are: 1) To determine the effect of countermeasures against the younger generation within the legal environment of the Karawang Police. 2) To determine the effect of drug trafficking on the younger generation within the Karawang Police District. 3) To find out the effect of joint control and distribution of drugs on the younger generation in the Karawang Police legal environment. "This research approach is quantitative, descriptive and associative. The population in this study were 120 young people in the Karawang Police District. Regarding the research, the author uses the Slovin technique. So the number of samples studied were 54 respondents, namely the younger generation in the Karawang Police District. "The results of this study indicate that: 1) There is an effect of tackling the younger generation, as evidenced by the ttable value for $n=54$ of 2,005. So 4.786 > 2,005, then HO is rejected and $\mathrm{Ha}$ is accepted, it can be stated that Countermeasures (X1) have a significant effect on the Young Generation The younger generation (Y). 2) There is an influence of Drug Circulation with the Young Generation, it is proven that the ttable value for $n=54$ is 2,005. So 9,693 > 2,005, then HO is rejected and Ha is accepted, it can be concluded that partially the Drug Circulation variable (X2) affects the Young Generation The younger generation (Y). 3) There is a joint effect of Drug Control and Circulation on the Young Generation, as evidenced by the Fcount value of 105,320, while Ftable (a 0.05) for $n=54$ is 2.78. So Fcount > from Ftable (a 0.05) or $105.320>2.78$ with a significant level of 0.000 because $0.000<0.05$, it can be said that Countermeasures (X1) and Drug Circulation (X2) are jointly positively related to the Young Generation (Y). While the $R$ value is 0.805 . This shows that $80.5 \%$ of Countermeasures (X1) and Drug Circulation (X2) are simultaneously related to the Young Generation (Y), while the remaining $19.5 \%$ are related to other factors not examined in this study. "Keywords: Countermeasures, Drug Circulation, Drugs, Young Generation
\end{abstract}

\section{PENDAHULUAN}

Informasi laba dapat digunakan oleh para pengguna laporan keuangan dalam menilai kinerja perusahaan (Uygur, 2013). Karena kecenderungan investor dan stakeholder yang lebih memperhatikan informasi laba, maka manajemen perusahaan akan terdorong untuk melakukan tindakan rekayasa laba (manajemen laba). Manajemen laba (earnings management) adalah keikutsertaan manajemen dalam menentukan laba yang diinginkan manajer dan sesuai dengan Standar Akuntansi Keuangan (SAK), (Febriyanti, 2014). Tindakan memodifikasi komponen akrual dalam laporan keuangan juga dapat dikatakan sebagai manajemen laba, (Sulistyanto (2008). Penerapan GCG dapat meningkatkan kualitas perusahaan dengan mewujudkan keseimbangan antara pengawasan dan pengendalian atas pengelolaan perusahaan yang mengarahkan agent (manajer) untuk memenuhi tujuan principal, yaitu kemakmuran pemegang saham dan nilai perusahaan.

\section{TINJAUAN PUSTAKA}

\section{Manajemen Laba}

Manajemen laba adalah tindakan seorang manajer perusahaan dengan cara mempengaruhi berbagai informasi dalam menyusun laporan keuangan (Sulistyanto, 2008). Pendapat lain dikemukakan oleh Scott (2012), yang menyatakan bahwa seorang manajer dapat memilih kebijakan akuntansi sesuai keinginannya untuk memperoleh laba yang diinginkan supaya tujuan secara spesifik dapat tercapai.

\section{Free Cash Flow}

Adanya teori keagenan akan menimbulkan konflik kepentingan sehingga memicu adanya manajemen laba. Suastawan (2014) menyatakan bahwa salah satu penyebab konflik yaitu adanya perbedaan kepentingan dalam pemanfaatan arus kas bebas perusahaan. Free cash flow (arus kas bebas) mempunyai hubungan positif dengan manajemen

\footnotetext{
* Dosen Fakultas Ekonomi dan Bisnis Institut Perbanas Jakarta
} 
laba, (Kangarluei dkk. 2011, Bhundia, 2012, Kodriyah dan Fitri, 2017). Sementara itu penelitian Agustia (2013), Kono dan Yuyetta (2013) mengatakan bahwa antara free cash flow dengan manajemen laba mempunyai hubungan yang negatif. Penelitian tersebut sejalan dengan Mappanyukki dkk (2016) yang menyimpulkan bahwa efek yang diberikan dari free cash flow terhadap manajemen laba adalah negatif. Tetapi menurut Bukit dan Nasution (2015) dalam penelitiannya menyebutkan bahwa arus kas bebas mempunyai pengaruh yang positif dengan manajemen laba. Hasil penelitian Rahadyan dan Purwanto (2015) juga menyimpulkan hasil yang serupa.

\section{Good Corporate Governance (GCG)}

Penerapan tata kelola perusahaan (good corporate governance) yang efektif diharapkan akan mengurangi manajemen laba di perusahaan/ Organization for Economic Cooperation and Development (OECD) menetapkan lima prinsip dasar yang digunakan sebagai framework GCG (Good Corporate Governance) yaitu fairness, transparency, accountability, responsibility, dan independency (Agoes, 2012). Saat ini, penilaian terhadap pelaksanaan GCG dilakukan oleh beberapa lembaga independen, salah satunya adalah Indonesian Institute for Corporate Governance (IICG). Hasil penelitian Ridwan (2013) menyimpulkan bahwa GCG mempunyai hubungan yang signifikan dengan manajemen laba. Loekita \& Sukartha (2016) juga menyatakan bahwa penerapan GCG dapat mengurangi manajemen laba secara efektif. Sedangkan penelitian Agustia (2013) dan Guna (2014) memberikan kesimpulan bahwa tindakan manajemen laba tidak dapat diturunkan dengan adanya praktik GCG. Aditama, Riyadi, dan Ingga (2018) juga membuktikan bahwa GCG berpengaruh signifikan terhadap manajemen laba secara negatif.

\section{Leverage}

Rasio leverage adalah perbandingan antara utang dengan aset perusahaan, sehingga perusahaan akan memiliki risiko yang besar apabila jumlah utangnya lebih besar daripada jumlah aset yang dimiliki perusahaan. Jika risikonya semakin besar maka perusahaan akan mengalami ketidakpastian yang semakin besar pula dalam menghasilkan laba di masa depan, (Agustia, 2013). Leverage berpengaruh negatif dengan manajemen laba maupun terhadap
Shareholder Wealth (Aditama, dkk. (2018). Sementara menurut Puspitasari, dkk (2019) mengatakan kalau leverage, mempunyai pengaruh yang positif teradap manajemen laba.

\section{HIPOTESISI}

Berdasarkan kajian teori dan hasil penelitian maka hipotesis diajukan sebagai berikut:

$\mathrm{H}_{1}$ : Free cash flow dapat mempengaruhi manajemen laba

$\mathrm{H}_{2}$ : Good corporate governance dapat mempengaruhi manajemen laba

$\mathrm{H}_{3}$ : Leverage dapat mempengaruhi manajemen laba

\section{Operasional Variabel \\ Manajemen Laba}

Tindak untuk manipulasi atau merekayasa laba dalam laporan keuangan adalah manajemen laba. Manajemen laba diukur dengan menggunakan discretionary accrual, dengan munggunakan Modified Jones Model, yang dapat ditentukan sebagai berikut:

1. Menghitung nilai total akrual sebagai berikut.

$$
T A_{i t}=\mathrm{NI}_{i t}-C F O_{i t}
$$

2. Menghitung nilai dari koefisien $\beta_{1}, \beta_{2}, \beta_{3}$ dengan menggunakan metode Jones model sebagai berikut.

$$
\text { TAit }=\beta_{1}+\beta_{2} \Delta R E V_{i t}+\beta_{3} P P E_{i t}+\varepsilon
$$

Kemudian menentukan formulasinya berubah menjadi sebagai berikut:

$\frac{T A_{i t}}{A_{i t-1}}=\beta_{1}\left(\frac{1}{A_{i t-1}}\right)+\beta_{2}\left(\frac{\Delta R e v_{i t}}{A_{i t-1}}\right)+\beta_{3}\left(\frac{P P E_{i t}}{A_{i t-1}}\right)+\varepsilon$

Selanjutnya mengestimasi total accrual dengan Ordinary Least Square untuk mendapatkan koefisien regresi $\beta_{1}, \beta_{2}, \beta_{3}$.

3. Menghitung nilai NDA dengan formulasi: $N D A_{i t}=\beta_{1}\left(\frac{1}{A_{i t-1}}\right)+\beta_{2}\left(\frac{\Delta \operatorname{Rev}_{i t}}{A_{i t-1}}-\frac{\Delta \operatorname{Rec}_{i t}}{A_{i t-1}}\right)+\beta_{3}\left(\frac{\mathrm{PPE}_{i t}}{A_{i t-1}}\right)$ Nilai dari koefisien $\beta_{1}, \beta_{2}$, dan $\beta_{3}$ adalah hasil dari perhitungan pada langkah ke-2.

4. Menentukan nilai discretionary accrual dengan cara sebagai berikut.

$$
D A_{i t}=T A_{i t} / A_{i t-1}-N D A_{i t}
$$

\section{Free Cash Flow (FCF)}

Menurut Kieso (2016), free cash flow adalah kas bersih yang disediakan oleh aktivitas operasi (CFO) dikurangi pengeluaran modal/capital expenditures (CAPEX) dan dividen. Rumus Kieso (2016), yaitu: Free Cash Flow $=\mathrm{CFO}-\mathrm{CAPEX}-$ Dividend 


\section{Good Corporate Governance (GCG)}

GCG dalam hal ini adalah merupakan skor Corporate Governance Perception Index (CGPI), yang diperoleh dari laporan Indonesian Institute for Corporate Governance (IICG) untuk periode tahun 2012 sampai tahun 2018. Hasil penilaian dengan parameter tersebut dituangkan ke dalam skor CGPI. Adapun kategori pemeringkatan CGPI yaitu jika memiliki skor 85-100 maka dikatakan sangat terpercaya; skor 70-84,99 dikatakan terpercaya; dan skor 55-69.99 dikatakan cukup terpercaya, (Sumber IICG).

\section{Leverage}

Rasio leverage adalah rasio yang menunjukkan besarnya utang untuk membiayai aktivitas operasional perusahaan, yang dijamin dari jumlah aset yang dimiliki oleh perusahaan, (Wijayanti dkk, 2020). Fahmi (2011:62) dalam Wijayanti dkk (2020), leverage diukur dengan total debt to aset ratio dengan rumus sebagai berikut:

Debt to Asset Ratio $($ DAR $)=\frac{\text { Total Hutang }}{\text { Total Aset }}$

\section{Populasi dan Teknik Sampel}

Data peserta CGPI adalah populasi dalam penelitian ini yang diambil dengan teknik purposive sampling, (Sugiyono, 2016). Sedangkan kriteria yang digunakan adalah: (1) Perusahaan yang pernah terdaftar menjadi peserta CGPI selama periode 20122018; (2) Perusahaan yang menerbitkan dan mempublikasikan laporan keuangan secara lengkap selama periode 2012-2018.; (3) Periode laporan keuangan yang berakhir pada tanggal 31 Desember; (4) Perusahaan yang memperoleh sertifikat CGPI secara konsisten selama periode 2012-2018. Rumus Slovin juga diterapkan dalam penelitian ini untuk memastikan bahwa jumlah sampel yang diambil telah memadai.

\section{Jenis dan Sumber Data}

Laporan keuangan perusahaan peserta CGPI periode 2012-2018 yang dipublikasikan pada website masing-masing perusahaan merupaka data sekunder yang digunakan dengan teknik dokumentasi dalam pengumpulan datanya. Penelitian ini juga menggunakan data laporan hasil riset dan pemeringkatan CGPI yang diperoleh dari Indonesian Institution for Corporate Governance (IICG).

\section{Analisis Data}

Dalam menganalisa data menggunakan metode regresi data panel, melakukan uji asumsi klasik dengan tingkat kepercayaan sebesar $95 \%$, serta dalam menguji hipotesis digunakan uji $\mathrm{f}$ dan uji t. Alat bantu yang digunakan untuk mencari keterkaitan antara variabel-variabel yang telah dijelaskan sebelumnya antara lain software Microsoft Excel dan SPSS versi 25.

\section{HASIL ANALISIS DAN PEMBAHASAN Deskripsi Objek Penelitian}

Laporan CGPI dan laporan keuangan perusahaan peserta CGPI yang mempublikasikan laporan keuangan baik melalui website Bursa Efek Indonesia maupun website masing-masing perusahaan selama periode 2012-2018, digunakan sebagai data penelitian, dengan sampel sebanyak 13 perusahaan.

\section{Uji F-Statistik}

Dari Tabel 1 dengan nilai signifikansi 0.000 maka dapat dikatkan bahwa variabel FCF, GCG dan Leverage secara simultan mempengaruhi manajemen laba.

Tabel 1 Hasil Uji F

\begin{tabular}{|c|c|c|c|c|c|c|}
\hline \multicolumn{7}{|c|}{ ANOVA $^{a}$} \\
\hline \multicolumn{2}{|c|}{ Model } & $\begin{array}{c}\text { Sum of } \\
\text { Squares }\end{array}$ & Df & $\begin{array}{c}\text { Mean } \\
\text { Square }\end{array}$ & $\mathrm{F}$ & Sig. \\
\hline \multirow[t]{3}{*}{1} & Regression & .515 & 3 & .172 & 22.432 & $.000^{\circ}$ \\
\hline & Residual & .666 & 87 & .008 & & \\
\hline & Total & 1.181 & 90 & & & \\
\hline
\end{tabular}

a. Dependent Variable: EM

b. Predictors: (Constant), FCF, GCG, Leverage

Sumber: Diolah peneliti dari SPSS 25

\section{Uji T-Statistik}

Hasil uji t-statistik ditunjukkan oleh Tabel 2.

Tabel 2 Uji T

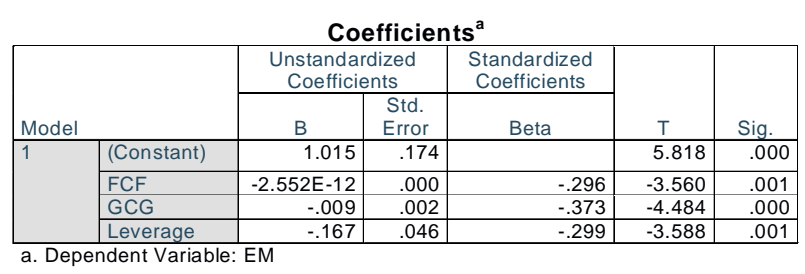

Sumber: Diolah peneliti dari SPSS 25

Dari uji t pada tabel 2 dapat dikatakan bahwa FCF dapat mempengaruhi manajemen laba secara signifikan sebesar 0.001. Demikian juga variabel GCG dan Leverage mempunyai nilai signifikansi kurang 
dari 0.05 yaitu sebesar 0.000 dan 0.001 , maka dapat dikatakan bahwa variabel tersebut dapat mempengaruhi manajemen laba. Ketiga variabel tersebut mempunyai arah negatif. Dalam pengolahan data diperoleh nilai 0.417 sebagai koefisien determinasi (adjusted $\mathrm{R}^{2}$ ), yang dapat disimpulkan bahwa variabel FCF, GCG dan Leverage dapat mempengaruhi variabel manajemen laba sebesar $41.7 \%$, sehingga sebesar $58.3 \%$ dijelaskan oleh variabel lain.

Tabel 3 Koefisien Determinasi

\begin{tabular}{|l|c|r|r|c|}
\multicolumn{7}{|c|}{ Model Summary $^{\mathbf{b}}$} \\
\hline Model & $\mathrm{R}$ & R Square & $\begin{array}{c}\text { Adjusted R } \\
\text { Square }\end{array}$ & $\begin{array}{c}\text { Std. Error of the } \\
\text { Estimate }\end{array}$ \\
\hline 1 & $.660^{\mathrm{a}}$ & .436 & .417 & .08749 \\
\hline
\end{tabular}

a. Predictors: (Constant), FCF, GCG, Leverage

b. Dependent Variable: EM

Sumber: Diolah peneliti dari SPSS 25

\section{PEMBAHASAN HASIL}

\section{Free Cash Flow (FCF) dapat mempengaruhi} Manajemen Laba

Berdasarkan hasil pengujian hipotesis diperoleh informasi bahwa FCF dapat mempengaruhi manajemen laba secara signifikan dengan arah negatif. Penelitian Agustia (2013) dan Mappanyukki dkk. (2016) juga menunjukkan hasil yang sama. Akan tetapi berbeda dengan penelitiannya Bukit dan Nasution (2015) maupun Kodriyah (2017) yang menyimpulkan bahwa FCF mempunyai pengaruh terhadap manajemen laba secara positif.

\section{Good Coporate Governance (GCG) dapat mempengaruhi Manajemen Laba}

Hasil pengujian hipotesis diperoleh informasi bahwa GCG dapat mempengaruhi manajemen laba secara signifikan dengan arah negatif, sehingga dapat disimpulkan bahwa adanya praktik GCG yang efektif pada perusahaan akan menekan praktik manajemen laba. Hal ini sejalan penelitian Loekita \& Sukartha (2016) maupun Aditama dkk. (2018). Perilaku oportunistik manajer yang mengutamakan kesejahteraan pribadi dapat diatasi karena penerapan good corporate governance mampu mewujudkan keseimbangan antara pengawasan dan pengendalian atas pengelolaan perusahaan yang bertujuan untuk kemakmuran pemegang saham (principal) dan peningkatan nilai/kinerja perusahaan. Sedangkan penelitian Agustia (2013) dan Guna (2014) menyimpulkan hasil yang tidak sejalan yakni GCG tidak dapat mempengaruhi manajemen laba. Berdasarkan penelitian ini, proksi skor CGPI dapat digunakan sebagai indikator untuk menunjukkan nilai GCG sebuah perusahaan. Semakin tinggi nilai GCG yang tercermin dalam skor CGPI sebuah perusahaan, maka terjadinya tindakan manajemen laba semakin kecil/rendah.

\section{Leverage dapat mempengaruhi Manajemen Laba}

Hasil uji hipotesis menunjukkan bahwa rasio leverage dapat mempengaruhi manajemen laba secara signifikan dengan arah negatif. Menurut penelitiannya Aditama,dkk (2018) rasio leverage mempunyai pengaruh signifikan dengan arah negatif terhadap manajemen laba. Demikian juga penelitan Agustia (2013) juga menyimpulkan bahwa rasio leverage dapat mempengaruhi berpengaruh manajemen laba. Puspitasari, dkk (2019) menyimpulkan bahwa leverage juga dapat mempengaruhi manajemen laba secara signifikan dengan arah positif.

\section{KESIMPULAN, KETERBATASAN DAN REKOMENDASI \\ Kesimpulan}

Dari hasil analisis disimpulkan bahwa FCF (free cash flow) dapat mempengaruhi manajemen laba secara signifikan, dengan koefisien regresi bernilai 0.296 dan nilai signifikansinya 0.001 , dengan demikian maka $\mathrm{H}_{1}$ diterima. Good corporate governance (GCG) memiliki koefisien regresi -0.373 dan nilai signifikansinya 0.000 , sehingga disimpulkan bahwa GCG dapat mempengaruhi manajemen laba secara signifikan, dengan kata lain $\mathrm{H}_{2}$ diterima. Leverage dapat mempengaruhi manajemen laba manajemen laba, dengan nilai koefisien regresi - 0.299 dan tingkat signifikansi 0.001, maka $\mathrm{H}_{3}$ diterima. FCF, GCG dan leverage yang dikelola dengan baik sehingga berada pada tingkat yang cukup tinggi secara bersama-sama mampu berkontribusi sebesar $41.7 \%$ dalam meminimalkan terjadinya manajemen laba.

\section{Keterbatasan}

Penelitian yang dilakukan memiliki keterbatasan antara lain:

1. Variabel independen yang digunakan hanya FCF, GCG dan leverage sehingga kemampuan model dalam menjelaskan perubahan nilai variabel dependen hanya sebesar $41.7 \%$. Dengan demikian sebesar $58.3 \%$ merupakan variabel independen lain yang mungkin dapat mempengaruhi manajemen laba. 
2. Periode pengamatan yang hanya 7 tahun sehingga hasil penelitian mungkin kurang dapat memberikan gambaran utuh atas pengaruh variabel independen terhadap variabel dependen pada perusahaan peserta CGPI.

3. Keikutsertaan beberapa perusahaan peserta CGPI tidak konsisten dari tahun ke tahun dan ada juga perusahaan yang tidak mempublikasikan laporan keuangannya sehingga berakibat pada kurangnya jumlah data atau objek penelitian.

\section{Rekomendasi}

Mengingat keterbatasan yang disampaikan maka penelitian selanjutnya direkomendasikan antara lain:

1. Menambahkan variabel independen lain yang dapat mempengaruhi variabel independen (manajemen laba). Hal ini disebabkan oleh masih terdapatnya variabel-variabel independen lain yang secara simultan mampu menjelaskan perubahan manajemen laba sebesar 58.3\%.

2. Menambah rentang waktu pengamatan, misalnya selama 10 tahun agar memperoleh gambaran yang lebih utuh atas pengaruh FCF, GCG leverage terhadap manajemen laba pada perusahaan peserta CGPI.

3. Penelitian serupa di masa mendatang dapat menambah jumlah data penelitian, tidak hanya pada perusahaan yang memiliki skor CGPI saja tetapi juga perusahaan dengan skor yang dikeluarkan perusahaan pemeringkat GCG lain seperti Corporate Governance Index oleh Indonesian Institute for Corporate Directorship (IICD). Selain itu, dapat juga dikembangkan pendekatan lain dalam mengukur variabel GCG misalnya dengan menggunakan penilaian self assessment yang terdapat pada laporan tahunan perusahaan.

\section{DAFTAR PUSTAKA}

Aditama, Buntar P, Slamet Riyadi, dan Ibrahim Ingga. 2018. Analisis Good Corporate Governance, Free Cash Flow, Leverage Terhadap Earning Management, dan Shareholder Wealth pada Perusahaan Sektor Jasa yang Tercatat di Bursa Efek Indonesia. Jurnal Ekonomi dan Bisnis Universitas 17 Agustus Surabaya, Vol 3, No 02.

Agoes, Sukrisno. 2012. Auditing Petunjuk Praktis Pemeriksaan Akuntan Oleh Akuntan Publik. Jilid 1. Edisi Keempat. Jakarta: Salemba Empat.
Agustia, Dian. 2013. Pengaruh Faktor Good Corporate Governance, Free Cash Flow, dan Leverage Terhadap Manajemen Laba. Jurnal Akuntansi dan Keuangan, Vol. 15, No 1, Mei 2013, 27-42.

Arikunto, S. 2010. Prosedur Penelitian Suatu Pendekatan Praktik. Jakarta: Rineka Cipta.

Bhundia, Amalendu. 2012. A Comparative Study Between Free Cash Flow and Earnings Management. Bussiness Intelligence Journal, 5(1), pp: 123-129.

Bukit, Rina Br dan Fahmi N. Nasution. 2015. Employee Diff, Free Cash Flow, Corporate Governance and Earnings Management. Procedia - Social and Behavioral Sciences. Procedia, p. 585-594.

Febriyanti, Anggie, Tjiptohadi Sawarjuwono, dan Bram Ade Pratama. 2014. "Manajemen Laba: Pro-Kontra Pemaknaan Antara Kreditur dan Debitur Dalam Proses Pembiayaan Kredit". Jurnal Manajemen dan Kewirausahaan, Vol. 16, No. 1, h. 55-67.

Guna, A. Muh. Idham Dwi. 2014. Analisis Pengaruh Good Corporate Governance, Leverage, dan Profitabilitas terhadap Manajemen Laba pada Perusahaan Manufaktur yang terdaftar di Bursa Efek Indonesia Tahun 2010-2013. Jurnal Akuntansi dan Bisnis Kontemporer Universitas Hasanuddin, Vol. 7, No. 1, hal 16-52.

Kangarluei, S.J., Morteza, M., and Taher, A. (2011). The Investigation And Comparison of Free Cash Flows In The Firms Listed In Tehran Stock Exchange (Tse) With An Emphasis On Earnings Management. Int. Journal of Economics and Business Modeling, 2(2), 118-1123.

Kieso, Weygandt dan Warfield. 2016. Akuntansi Intermediate. Jakarta: Erlangga.

Kodriyah dan Anisah Fitri. 2017. Pengaruh Free Cash Flow dan Leverage Terhadap Manajemen Laba Pada Perusahaan Manufaktur di BEI. Jurnal Akuntansi LPPM Unsera. Vol. 3 No. 2. Hal 64-76.

Kono, Fransiska Dian Permatasari dan Etna Nur Afri Yuyetta. 2013. Pengaruh Arus Kas Bebas, Ukuran KAP, Spesialisasi Industri KAP, Audit Tenur dan Independensi Auditor Terhadap Manajemen Laba. Diponegoro Journal of Accounting, Vol. 2, No. 3, h.1-9. 
Loekita, Vicentius Kelvin Kristianto dan I Made Sukartha. 2016. Pengaruh Good Corporate Governance Pada Manajemen Laba Perusahaan Pengakuisisi Sebelum Merger dan Akuisisi. E-Jurnal Akuntansi Universitas Udayana, Vol.14, No.2, h. 1064-1090.

Mappanyukki, Ratna, Haryo Dwi Prakoso, dan Soni Agus Irwandi. 2016. The Impact of Free Cash Flow and Good Corporate Governance (GCG) on Earning Management of the Banking Companies Listed on the Indonesia Stock Exchange. Research Journal of Finance and Accounting. Vol 7, No 20, hal 87-99.

Puspitasari, Emy Puji, Nur Diana, dan M. Cholid Mawardi. 2019. Pengaruh Faktor Good Corporate Governance, Free Cash Flow, dan Leverage Terhadap Manajemen Laba pada

Perusahaan Batu Bara. Jurnal Ilmiah Riset Akuntansi Universitas Islam Malang, Vol 8, No 03.

Rahadyan W., S. Willy dan Agus Purwanto. 2015. Pengaruh Surplus Free Cash Flow Dan Mekanisme Good Corporate Governance Terhadap Manajemen Laba. Diponegoro Journal of Accounting, Volume 4, Nomor 2.

Ridwan, Mochammad dan Gunardi A(2013). "Peran Mekanisme Corporate Governance sebagai Pemoderasi Praktik Earning Management terhadap Nilai Perusahaan." Fakultas Ekonomi Universitas Pasundan, Volume 12, No. 1, Juni 2013, Hal. 49-60 ISSN 1411-514X.
Scott, W. R. (2012). Financial Accounting Theory 6th edition. Toronto: Pearson Education Canada.

Suastawan, I Putu. 2014. Pengaruh Arus Kas Bebas dan Profitabilitas pada Kebijakan Utang Perusahaan Real Estate. E-Jurnal Akuntansi Universitas Udayana, Vol. 9, No. 3, hal. 684694.

Sugiyono. 2016. Metode Penelitian Kuantitatif, Kualitatif dan $R \& D$. Bandung: PT Alfabet.

Sulistyanto, H. Sri. 2008. Manajemen Laba Teori dan Model Empiris. Jakarta: Grasindo.

Uygur, O. (2013). Earnings management and executive Compensation/ : Evidence from banking industry Earnings Management and Executive Compensation/ : Evidence from Banking Industry. Banking \& Finance Review, 5(2), 33-54.

Wijayanti, I., Mawardi, R., Jasman, \& Halim, A., B. (2020). The Effect Of Corporate Social Responsibility Disclosure, Leverage, Firm Size, And Profitability Toward Earning Response Coefficient. International Journal Of Innovation, Creativity And Change. 13(3). 